\title{
A comparative study of swimming behavior in eight species of muroid rodents
}

\author{
ROBERT L. EVANS, ELLIOT M. KATZ, NANCY L. OLSON, \\ and DONALD A. DEWSBURY \\ University of Florida, Gainesville, Florida 32611
}

\begin{abstract}
Ten males and females from each of eight species of muroid rodents were tested for their tendency to leave a dry platform and swim in 5-min tests. Overall, $85 \%$ of the animals entered the water at least once and all showed integrated swimming behavior, even though they had not previously encountered standing water. There were no consistent sex differences. Species differences were found with respect to the latency to enter the water, the number of bouts of swimming, the total time swimming, and the mean swim bout duration. These species differences could not be related to ecological factors in the natural habitat.
\end{abstract}

It is generally believed that most terrestrial mammals are capable of swimming, or of at least keeping themselves at the surface of the water, if the need arises. Bourliere (1964) noted only elephants and some species of great apes as exceptions to this general rule. However, there have been few systematic comparative studies of swimming behavior.

The muroid rodents are an ideal taxon for comparative behavioral studies, as they are adapted to a wide range of habitats, yet represent a relatively restricted taxonomic group (Dewsbury, 1974). There are numerous reports of swimming among muroid rodents. Orr (1933) observed a deer mouse swim across a 10-ft stream, while Teeters (1945) observed a white-footed mouse cross a 30-ft stream. Sheppe (1965) found white-footed mice stayed afloat for $1 / 2 \mathrm{~h}$ or more when released from a boat. The development of swimming in two subspecies of deer mice was studied by King (1961), who found coordinated swimming movements at 10 , 12 , and 14 days of age. The most systematic comparative study of swimming was that of King, Price, and Weber (1968), and included Peromyscus mice of eight different taxa (seven species and two subspecies of P. maniculatus). Significant differences in swimming behavior were found among the taxa, but these could not be related to ecological adaptations in the field.

In the present study we adapt the methods of King et al. (1968) in order to extend their observations more broadly within the superfamily Muroidea. Four sets of questions are asked. First, will laboratory-reared animals without prior exposure to standing water display coordinated swimming? Second, will there be any differences between males and females regarding the propensity to swim? Third, will there be species differences with respect to the propensity to swim? Finally, will it be

This research was supported by Grant BMS75-08656 from the National Science Foundation. Requests for reprints should be addressed to D. A. Dewsbury. possible to relate any species differences to ecological adaptations characteristic of the species? It would be anticipated that species living in very moist habitats or in habitats subjected to periodic flooding might be more likely to swim than species from drier habitats.

\section{METHOD}

\section{Subjects}

The subjects were 160 muroid rodents between 40 and 60 days of age. There were 10 males and 10 females from each of the following eight species: Microtus ochrogaster (prairie voles), M. pennsylvanicus (meadow voles), M. canicaudus (graytailed voles), M. montanus (montane voles), Mus musculus (house mice), Peromyscus leucopus (white-footed mice), $P$. eremicus (cactus mice), and $P$. maniculatus bairdi (deer mice). All animals came from colonies maintained at the University of Florida and were derived from stock that was wild-trapped, but maintained in the laboratory for at least three generations. Animals were kept on reversed diurnal cycles with 14-15 h of white light per day. No animals had any prior experience with either standing water or the experimental situation.

\section{Apparatus}

Tests were conducted in a clear plastic cage, $37 \times 49 \times 20 \mathrm{~cm}$ and filled with tap water to a depth of approximately $11 \mathrm{~cm}$. The water was maintained at a temperature of $29 \pm 1^{\circ} \mathrm{C}$. A cube with sides $12 \mathrm{~cm}$ long was constructed of hardware cloth and placed in the center of the cage. Thus, there was a dry area approximately $1 \mathrm{~cm}$ above the water level and $144 \mathrm{sq} \mathrm{cm}$ in area in the center of a cage filled with water. Immediately before testing, the animals were restrained in an opaque plastic cup, open at both ends, approximately $10 \mathrm{~cm}$ deep, and with ends measuring 7.5 and $9.5 \mathrm{~cm}$. The entire apparatus was placed inside a cardboard carton $62 \mathrm{~cm}$ high in order to prevent escapes. Data were recorded on an Esterline-Angus operations recorder.

\section{Procedure}

Each animal received a single test conducted during the first $1 \mathrm{~h}$ of the dark phase of its diurnal cycle. The plastic cup was placed on the hardware cloth cube, and the animal then placed inside of it, with the experimenter's hand covering the top to prevent escape. The cup was removed after $1 \mathrm{~min}$, thus starting the test. Each animal was left in the apparatus for a period of $5 \mathrm{~min}$. At the end of each test, the animal was removed and dried under a heat lamp. 
Periods of swimming were recorded on the operations recorder. From these records the following measures were derived: latency to swim-time from removal of the cup until the first entry into the water; total time swimming-total amount of time the animal spent in the water; number of bouts swimming-the number of times the animal entered the water from the cube during the 5-min test; mean swim bout duration-the mean length of time spent in the water per entry.

\section{RESULTS}

Mean scores for various measures of swimming behavior are presented in Table 1. At least half of the animals in each group entered the water and swam at some time during their tests. All showed coordinated swimming and were able to remain near the surface of the water. Chi-square tests revealed no significant differences across species in the proportion of animals swimming.

Kruskal-Wallis one-way analyses of variance (Siegel, 1956) were used to evaluate species difference. There were significant differences on all four dependent variables. One problem in data analyses was that of how to treat scores from tests in which the animal never entered the water. Such tests are scored as having latencies of $300 \mathrm{sec}$, with no bouts of swimming, and a total time swimming of zero. However, such tests were eliminated from the analyses of mean bout duration, as mean bout duration would make little sense where there were no bouts. When tests with no swimming were deleted from analyses of the latency data, the species difference remained significant $(\mathrm{H}=28.6, \mathrm{df}=7$, $\mathrm{p}<.001)$.

Table 1

Mean Scores for Measures of Swimming Behavior in Eight Species of Muroid Rodents

\begin{tabular}{|c|c|c|c|c|c|c|}
\hline Species & Sex & $\begin{array}{c}\% \text { of } \\
\text { Ani- } \\
\text { mals } \\
\text { Swim- } \\
\text { ming }\end{array}$ & $\begin{array}{l}\text { Laten- } \\
\text { cy to } \\
\text { Swim* }\end{array}$ & $\begin{array}{c}\text { No. of } \\
\text { Bouts } \\
\text { Swim- } \\
\text { ming }\end{array}$ & $\begin{array}{l}\text { Total } \\
\text { Time } \\
\text { Swim- } \\
\text { ming* }\end{array}$ & $\begin{array}{c}\text { Mean } \\
\text { Swim } \\
\text { Bout } \\
\text { Dura- } \\
\text { tion* }\end{array}$ \\
\hline Microtus & $\mathbf{M}$ & 50 & 170.3 & .9 & 26.6 & 45.8 \\
\hline pennsylvanicus & $\mathrm{F}$ & 70 & 98.7 & .7 & 34.7 & 49.6 \\
\hline Microtus & $\mathbf{M}$ & 100 & 38.5 & 1.3 & 42.3 & 32.7 \\
\hline montanus & $\mathrm{F}$ & 80 & 79.3 & 1.4 & 71.3 & 54.5 \\
\hline Microtus & M & 60 & 153.0 & .9 & 23.7 & 46.4 \\
\hline canicaudus & $\mathrm{F}$ & 50 & 187.8 & .7 & 17.6 & 32.0 \\
\hline Microtus & M & 100 & 37.3 & 1.9 & 55.2 & 26.2 \\
\hline ochrogaster & $\mathrm{F}$ & 90 & 31.9 & 1.5 & 116.2 & 76.8 \\
\hline Peromyscus & M & 100 & 8.4 & 1.8 & 55.9 & 42.7 \\
\hline maniculatus & $\mathrm{F}$ & 100 & 6.2 & 1.5 & 112.9 & 81.7 \\
\hline Peromyscus & M & 100 & 6.4 & 2.4 & 126.7 & 60.3 \\
\hline leucopus & $\mathrm{F}$ & 90 & 72.0 & 1.9 & 40.9 & 24.1 \\
\hline Peromyscus & $\mathrm{M}$ & 80 & 93.1 & 1.1 & 36.6 & 41.4 \\
\hline eremicus & $\mathrm{F}$ & 100 & 50.3 & 1.3 & 77.6 & 76.8 \\
\hline Mus & M & 90 & 42.4 & 2.7 & 30.6 & 11.4 \\
\hline musculus & $\mathrm{F}$ & 100 & 13.7 & 2.2 & 36.9 & 18.4 \\
\hline $\mathrm{H}$ & \multicolumn{4}{|c|}{$45.8+38.2+$} & $29.2 \dagger$ & $15.4^{* *}$ \\
\hline
\end{tabular}

*Measured in seconds.

${ }^{* *} p<.05 \quad t p<.001$
Pairwise comparisons were made using Nemenyi's procedure for simultaneous statistical inference following a significant Kruskal-Wallis (Miller, 1966). The following comparisons were significant at least to the .05 level. For latency: P. maniculatus faster than $M$. pennsylvanicus and M. canicaudus; M. ochrogaster and M. montanus faster than $M$. canicaudus. For number of bouts: P. leucopus and Mus musculus greater than M. pennsylvanicus and M. canicaudus. For total time swimming: M. ochrogaster and P. maniculatus greater than $M$. canicaudus. For mean swim bout duration: none.

Sex differences were evaluated for each species and measure using Mann-Whitney U tests. Just 3 of 32 comparisons were significant at the .05 level. Male $M$. ochrogaster had longer latencies than females $(\mathrm{U}=20, \mathrm{p}<.05)$, female $P$. leucopus had longer latencies than males $(\mathrm{U}=8.5, \mathrm{p}<.002)$, and Mus musculus females had longer mean swim bout durations than males $(\mathrm{U}=18, \mathrm{p}<.05)$.

\section{DISCUSSION}

The first of the four questions posed in this research was concerned with the extent to which laboratory-reared animals would enter water and show coordinated swimming behavior. Overall, 136 of 160 animals (85\%) entered the water during the 5 -min tests; all others entered the water and swam when the experimenter reached for them at the conclusion of testing. Thus, under these conditions, most animals swam during the test period, whereas all appeared able to swim. Significant sex differences were found in just 3 of 32 comparisons. Given the relatively small number of significant differences and the lack of an orderly pattern, we conclude that we are unable to detect any consistent sex differences.

Significant species differences were found on all four dependent variables. One might define a "good" swimmer as one which enters the water with a short latency and has a high total of time swimming. By these criteria, P. maniculatus and $M$. ochrogaster would appear to be the best swimmers and $M$. canicaudus and M.pennsylvanicus the worst swimmers under the present conditions. Of the species studied here, $P$. eremicus, $P$. leucopus, and $P$. $m$. bairdi also were studied by King et al. (1968). None stood out substantially from the other five taxa studied in the latter study. Similarly, there were no significant differences among these species in the present study.

Our final goal was to relate swimming behavior in the laboratory to ecological factors in the natural habitat. There is no obvious relationship. For example, $M$. canicaudus, the poorest swimmer in our sample, lives in areas that sometimes are flooded, so that they sometimes have to dive through flooded burrows to get to their dry nests. "The high water, if not too high or prolonged, does not seem to bother the voles" (Maser \& Storm, 1970). Where $M$. ochrogaster, one of the better swimmers, and $M$. pennsylvanicus, one of the poorer swimmers, occur sympatrically, it is the latter that lives in the wetter habitat (Getz, 1962; Miller, 1969). Peromyscus maniculatus bairdi, a good swimmer, generally occupies uplands in preference to swales or marshes (King et al., 1968).

The tendency to enter the water in a situation such as this is a joint function of many factors, only one of which is the attractiveness or aversiveness of the water. In reviewing the comparative data of King et al. (1968), King (1970) wrote: "The test situation probably measured the relative aversiveness of the wire platform and the water: those species most aversely affected by sitting exposed on the platform and least aversely 
affected by entering the water tended to swim most often" (p. 500). A similar impression may be gained from the present study. Thus, the latency to enter the water may be as much a function of the tendency either to leap when first freed from the release cup or to jump from the platform as to swim per se. Our only relevant independent data are concerned with the latencies of seven of these species to descend from a platform in a test of visual cliff behavior (Sloane, Shea, Procter, \& Dewsbury, in press). The rank-order correlation between latency to swim and latency to descend from the center board of the visual cliff was +.64 and approached statistical significance $(p>.05)$. As there can be no "pure" test of swimming, its relative attractiveness or aversiveness may have to be tested in relation to a variety of alternatives in different situations.

\section{REFERENCES}

BoURLIERE, F. The natural history of mammals. (3rd ed.) New York: Knopf, 1964

DEwsBury, D. A. The use of muroid rodents in the psychology laboratory. Behavior Research Methods \& Instrumentation, 1974, 6, 301-308.

GETZ, L. L. Aggressive behavior of the meadow and prairie voles. Journal of Mammalogy, 1962, 43, 351-358.

KING, J. A. Swimming and reaction to electric shock in two subspecies of deermice (Peromyscus maniculatus) during development. Animal Behaviour, 1961, 9, 142-150.

KIng, J. A. Psychology. In J. A. King (Ed.), Biology of Peromyscus (Rodentia). Lawrence, Kans: American Society of Mammalogists, 1970. Pp. 496-542.

King, J. A., Price, E. O., \& Weber, P. L. Behavioral comparisons within the genus Peromyscus. Papers of the Michigan Academy of Science, Arts, and Letters, 1968, 53, 113-135.

MASer, C., \& Storm, R. M. A key to the Microtinae of the Pacific Northwest. Corvallis, Oreg: Oregon State University Book Stores, 1970.

Miller, R. G. Simultaneous statistical inference. New York: McGraw-Hill, 1966.

Miller, W. C. Ecological and ethological isolating mechanisms between Microtus pennsylvanicus and Microtus ochogaster at Terre Haute, Indiana. American Midland Naturalist, 1969, 82, 140-148.

ORR, R. T. Aquatic habits of Peromyscus maniculatus. Journal of Mammalogy, 1933, 14, 160-161.

ShePpe, W. Dispersal by swimming by Peromyscus leucopus. Journal of Mammalogy, 1965, 46, 336-337.

SIEGEL, S. Nonparametric statistics for the behavioral sciences. New York: McGraw-Hill, 1956.

Sloane, S. A., Shea, S. L., Procter, M. M., \& Dewsbury, D. A. Visual cliff performance in 10 species of muroid rodents. Animal Learning \& Behavior, in press.

TEETERS, R. Swimming ability of a wood mouse. Journal of Mammalogy, 1945, 26, 197.

(Received for publication December 7, 1977.) 